\title{
Risikofaktorer for suicidal atferd blant unge i Norge
}

\author{
Berit Grøholt \\ Sogn Senter for Barne- og Ungdomspsykiatri, Instituttgruppe for psykiatri, Universitetet i Oslo \\ Korrespondanse: Berit Grøholt, SSBU, boks 26 Vindern, 0319 Oslo \\ Telefon: 23492100 el. 23492326 Telefaks: 22028641 e-post: berit.groholt@psykiatri.uio.no
}

\begin{abstract}
SAMMENDRAG
Tre grupper av unge med suicidal atferd sammenliknes; unge som døde av suicid $(\mathrm{N}=129)$, unge som gjorde selvmordsforsøk og ble hospitalisert $(\mathrm{N}=92)$, og unge som har skadet seg selv, men ikke ble innlagt på sykehus $(\mathrm{N}=141)$. Alle gruppene omfatter unge til og med 19 år, og er sammenliknet med gjennomsnittsungdom fra spørreundersøkelsen "Ung i Norge". Variabler knyttet til psykisk helse, sosial situasjon og forhold til andre ble inkludert i analysene. For selvmordsstudien var få sosiale variabler inkludert. I multivariate analyser fant vi at depresjon, utagerende atferd og lav selvfølelse øket risiko for all suicidal atferd, på en måte som indikerte en kontinuitet knyttet til alvorlighetsgrad mellom de ulike suicidale gruppene. Negative ytre forhold (sosiale forhold, forhold til andre) hadde klarest sammenheng med alvorlige selvmordsforsøk. De unge som søkte støtte hos foreldre ved behov var delvis beskyttet. De som søkte støtte fra venner viste suicidal atferd, men sjelden slik at det førte til innleggelse. Konsekvenser av disse forskjellene, bl.a. for forebyggende tiltak, diskuteres.
\end{abstract}

\section{Grøholt B. Risk factors for suicidal behaviour among young people in Norway. Nor J Epidemiol 2002; 12 (3): 207-214.}

\section{ENGLISH SUMMARY}

Studies related to different types of suicidal behaviours are reported and findings compared. In casecontrol designed studies, risk factors for suicide $(\mathrm{N}=129)$, hospitalised suicide attempt $(\mathrm{N}=92)$ and deliberate self-harm $(\mathrm{N}=141)$ are estimated. Mental disorders, above all depression, increased the risk for all types of suicidal behaviours, in a manner indicating a continuum of severity between the different behaviours. Also behaviour problems and low self-esteem showed this pattern. Information about social and family problems was scarce regarding suicide. These problems seemed to have the strongest association with hospitalised self-harm. Young people who asked for support from parents or peers seemed to have a relative protection. Peer support protected against self-harm leading to hospitalisation, while parent support also protected against the less serious deliberate self-harm. The practical consequences of these findings are discussed.

\section{INNLEDNING}

Selvmordsratene i Norge har endret seg betydelig de siste 30 årene. Ratene var relativt stabile fram til 1970, men steg så jevnt fram til 1988. Sterkest var økningen for unge menn. For aldersgruppen 25-29 år steg raten fra 13/100000/år i 1970 til 36/100000/år i 1988. Dette året kulminerte antallet selvmord med 708 registrerte selvmord i Norge. I det siste tiåret har det skjedd en betydelig reduksjon, og i 1996 var antallet selvmord sunket til 517. Etter dette har vi sett en svakt økende tendens. Interessant er det at reduksjonen i liten grad har omfattet de yngste. I 1988 var selvmordsraten for gutter 15-19 år 21,9/100000/år. For perioden 19891994 var gjennomsnittlig rate 18,3 og for perioden 1995-1999 16,3. I 1999 var raten 19,9. Blant tenåringspikene har det skjedd en økning. Raten var i 1988 3,7, og i 1999 12,4. Gjennomsnittlig rate for 1989-1994 var 5,5 og for 1995-1999 7,7.
Spørsmålet om hvorfor reduksjonen i antall selvmord har funnet sted har meldt seg med full styrke, uten at noe klart svar er funnet. Det som har hatt effekt, har ikke hatt samme effekt på alle alderstrinn. En forandring som har funnet sted er en økt offentlig satsing på selvmordsforebygging i Norge, med øket kunnskap til fagfolk og lekfolk. At opplysningskampanjer har mindre effekt $i$ forhold til de yngste er en sannsynlig antagelse. Imidlertid kan den tendensen vi har sett i Norge kjennes igjen i mange land som ikke har hatt samme type satsing. Også i USA, Danmark og Sverige hadde man en topp sent i 80-årene, med en betydelig reduksjon i ratene etter dette (1). Selv om vår kunnskap om hva som ligger bak reduksjonen er mangelfull, er målet om å redusere selvmord og selvmordsatferd like klart, og ønsket om en reduksjon også blant de yngste er høyt prioritert.

Kunnskap om risikofaktorer for suicid og suicidal atferd blant unge i Norge vil gjøre det lettere å finne 
fram til potensielt virksomme selvmordsforebyggende tiltak for denne gruppen. Fra internasjonal litteratur finnes mange studier som beskriver risikofaktorer for selvmordshandlinger. Generelt har man hentet kunnskap fra studier basert på gjennomførte selvmord, av personer som har foretatt mer alvorlige selvmordsforsøk, eller på epidemiologiske spørreundersøkelser om selvmordsatferd $i$ befolkningen. Vi vet imidlertid lite om kunnskaper om en av gruppene er relevant for de andre. For eksempel: Kan vi anvende kunnskap med utgangspunkt i selvmordsatferd i befolkningsgrupper når vi planlegger forebygging av selvmord? Fra tidligere har vi i Norge befolkningsstudier av ungdom som har gitt kunnskap om risikofaktorer for selvmordsforsøk $(2,3)$, og vi har kunnskap om risikofaktorer for selvmord for spesielt utsatte ungdomsgrupper som har mottatt psykiatrisk behandling (4).

I det følgende vil vi beskrive funn fra to norske undersøkelser som kartlegger risikofaktorer for ulike typer suicidal atferd blant norsk ungdom. Studiene omfatter selvmord, selvmordsforsøk som fører til sykehusinnleggelse, og rapportert selvskade/selvmordsforsøk i befolkningen. Vi vil beskrive risikofaktorene, og vi vil se om de samme faktorene er assosiert med alle typer selvmordshandlinger. Det er også vel kjent at mange unge karakterisert av velkjente risikofaktorer ikke viser suicidal atferd, og for å komme et skritt nærmere en forståelse av prosessen bak en selvmordshandling vil vi også se på potensielt beskyttende faktorer.

\section{MAteriale OG MEtode}

\section{Materiale}

Studie 1 omfattet alle dødsfall hos personer under 20 år, registrert som selvmord i Norge i treårsperioden fra 1990-92. Det omfattet 30 piker og 99 gutter, og disse 129 unge avdøde utgjorde GRUPPE A Gjennomført selvmord (figur 1). Undersøkelsen baserer seg på opplysninger fra politi, allmennleger samt obduksjonsrapport, inkludert i alt 44 avskjedsbrev. Der det framkom opplysninger om hjelpetiltak fra psykiatrisk og somatisk helsevesen, fra barnevern og fra skolepsykologisk tjeneste, ble informasjon innhentet fra disse kildene (5). I gjennomsnitt var det 3,2 informanter (fra 2 til 7) per selvmord. Tillatelse var gitt fra Regional komite for medisinsk forskningsetikk, Datatilsynet, Barne- og familiedepartementet, Sosial- og helsedepartementet, Utdanningsdepartementet, Riksadvokaten og Rådet for taushetsplikt og forskning. De vanligste selvmordsmetodene var henging $41 \%$ (gutter $38 \%$, piker $50 \%$ ), skyting 39\% (gutter $43 \%$, piker 23\%), bileksos $8 \%$ (gutter 9\%, piker 3\%), medikamentforgiftning 5\% (gutter 3\%, piker 13\%). Få (7\%) døde ved drukning, sprang fra høyde eller ved å kaste seg foran et kjøretøy.

Studie 2 omfattet 92 unge under 20 år, 83 piker og 9 gutter, alle innlagt på somatisk sykehus i Oslo eller Akershus etter et selvmordsfors $ø$ k mellom september
1993 og november 1994. Disse 92 kalles GRUPPE B alvorlig selvmordsforsøk og utgjorde $86 \%$ av alle innleggelser pga. selvmordsfors $ø$ k i perioden. De 92 ble intervjuet $\mathrm{i}$ forbindelse med selvmordsforsøket. Gjennomsnittlig var det 4,9 timers kontakt ( $\mathrm{SD}=1,4$ timer), som i $71 \%$ av tilfellene også inkluderte kontakt med familiene. Betegnelsen alvorlig selvmordsforsøk betyr at alle var innlagt på sykehus, men impliserer ikke nødvendigvis at den medisinske tilstanden var alvorlig. Ifølge kriterier satt opp av Beautrais var 41 (45\%) selvmordsforsøk kategorisert som medisinsk alvorlige (6). De fleste ble innlagt pga. medikamentforgiftning (96\%), noen forsøkte å henge seg (1\%) eller å skyte seg (1\%). Sammen med en av disse metodene kuttet 6 seg opp.

\section{Sammenlikningsgrupper}

Studie 1. Sammenlikningsgrupper er hentet fra studien "Ung i Norge". Et representativt utvalg av norske skoleungdommer (12-20 år) deltok i en omfattende spørreundersøkelse først i $1992(\mathrm{~N}=11315)$ og igjen i $1994(\mathrm{~N}=8573)(3,7,8)$. I studie 1 trakk vi ut 7 personer matchet for kjønn og alder for hver av de unge som var over 10 år og døde ved selvmord (127 av de 129). I alt ble 889 personer (GRUPPE C) trukket ut av første fase i "Ung i Norge"-undersøkelsen i 1992 (figur 1).

Studie 2. I neste runde i Ung i Norge-undersøkelsen i 1994, ble alle deltagere fra Oslo og Akershus inkludert i sammenlikningsgruppen, i alt 1736 (GRUPPE D). Blant disse 1736 rapporterte 141 at de hadde skadet seg selv med vilje en eller flere ganger eller foretatt selvmordsforsøk, og disse utgjorde GRUPPE E selvmordsatferd (selvskade) $i$ befolkningen. Av de som oppga skademetode $(\mathrm{N}=48)$, rapporterte $33 \%$ at de hadde tatt piller, mens $47 \%$ hadde skåret seg, og $20 \%$ brukte andre metoder.

\section{Målemetoder og analyse}

Studie 1. I studien av gjennomførte selvmord ble psykisk helse vurdert etter DSM-III R-kriterier, basert på all tilgjengelig informasjon. Diagnoser er rapportert tidligere (5). Her rapporteres bare prevalens av depressiv lidelse og atferdsforstyrrelse. Andre registrerte forhold er: Tidligere selvmordsforsøk, hyppig bruk av rusmidler (beruselse de fleste weekender, eller mer enn 50 ganger $\mathrm{i}$ ett år) og om de unge bodde sammen med to biologiske foreldrene (for nærmere beskrivelser se (5)). Samme data hadde vi i sammenlikningsgruppen GRUPPE C fra Ung i Norge fra 1992 (8). Her ble depresjon målt med Depressive Mood Inventory (DMI) (9). Atferdsforstyrrelse ble vurdert i forhold til DSM III R, etter spørsmål utviklet av Wichstrom (8).

Studie 2. I sammenlikningen mellom GRUPPE B (alvorlig selvmordsforsøk) og GRUPPE D (gjennomsnittsungdom fra Ung i Norge 1994) ble langt flere variabler inkludert. Depresjon ble vurdert klinisk, og med Beck Depression Inventory (9) i den kliniske 
Studie 1

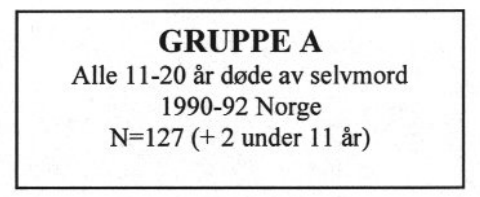

\section{GRUPPE C}

7 unge for hvert selvmord, matchet for kjønn og alder $\mathrm{N}=889$ Norge

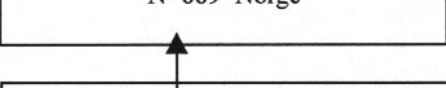

Ung i Norge 1992. 12-20 år $\mathrm{N}=11315$ Hele landet
Studie 2

\section{GRUPPE B}

Innlagt i sykehus etter "alvorlig selvmordsforsøk" Oslo og Akershus 1993-94 $\mathrm{N}=92$

\section{GRUPPE D}

Alle i Oslo og Akershus i 1994, N=1736
GRUPPE E

141 av 1736 med selvskade

Sammenlikningsgrupper trukket fra Wave 1 og Wave 2 i Ung i Norge

Figur 1. Oversikt over studie 1 og studie 2.

gruppen B og med DMI (Depressive Mood Inventory) i sammenlikningsgruppen D (10). Atferdsforstyrrelse ble målt som i studie 1 , men nå tilpasset DSM IV (8). Vi hadde mål for sosial klasse (ISCO 88) (8), om de unge levde med to biologiske foreldre og om de opplevde foreldrene sine beruset mer enn et par ganger i måneden. De unge hadde rapportert hvem de vanligvis omgikk; (en gjeng av unge; med enkelte venner; eller ingen, evt. mer tilfeldige bekjente), om de brukte ulovlige rusmidler og om de hadde skulket skolen mer enn 10 dager siste år. Videre hadde vi et mål for ensomhet (UCLA loneliness scale, (1-4, 1=best, totalskåre 4-16) (11) og for global selvfølelse (fra SPPA) (1-4, 4=best, totalskåre 5-20) (12,13). Alle hadde også rapportert hvem de ville gå til hvis de hadde problemer (følte seg nedfor; hadde problemer med myndigheter som politiet; skulle velge utdanning). Det ga et mål fra 0-3 (3=ber om støtte i alle situasjonene) for hvor ofte de gikk til foreldre eller venner, respektive, eller til noen overhode. Alle mål er beskrevet i tidligere artikler $(14,15)$.

GRUPPE E (selvmordsatferd i befolkningen) var en del av sammenlikningsgruppen D fra Ung i Norge 1994. Vi sammenliknet dem med resten av gruppe D med instrumentene nevnt over.

\section{Dataanalyse}

Alle rapporterte analyser er utført som logistiske regresjoner for matchede sett (16) med programmet LogExact-Turbo (1993). Effekten av hver variabel er angitt som justert odds ratio (OR) i de multivariate analysene, der alle variabler med signifikant bivariat effekt er tatt inn. For de kontinuerlige variablene angir OR effekten av en økning på en i totalskåren. Resultat fra bivariate analyser er delvis angitt i teksten, og i sin helhet finnes de i tidligere publikasjoner $(5,15)$. Det angis alltid 95\% konfidensintervall.

\section{RESUltater}

Resultater fra sammenlikningene over er detaljert beskrevet i forfatterens doktorarbeid (14). Her rapporteres prevalens av de viktigste risikofaktorer. Vi har ikke rapportert prevalenser i sammenlikningsgruppe $\mathrm{C}$ fra Ung i Norge 1992, da den ikke avviker vesentlig fra sammenlikningsgruppe D fra Ung i Norge 1994. Alle de tre suicidale gruppene har forhøyet prevalens av alle målte risikofaktorer sammenliknet med gjennomsnittsungdom. Bare for de suicidale fra befolkningsundersøkelsen (gruppe E) fant vi noen unntak (tabell 1).

\section{Psykiske vansker og atferdsproblemer}

Vi ser av tabell 1 at depresjon og atferdsforstyrrelser forekommer omtrent like ofte blant de som dør (gruppe A) eller innlegges på sykehus etter selvmordsforsøk (gruppe B). Cirka halvparten er deprimerte (A: $45 \%$ og B: $53 \%$ ) og en snau femtedel er atferdsforstyrret (A: 17\% og B: 19\%). Denne likheten finner vi på tross av at de døde (gruppe A) domineres av gutter og de innlagte (gruppe B) av piker. Et tidligere selvmordsforsøk, før den handlingen som førte til at de ble med i studiene, ble registrert noe oftere hos de med alvorlig selvmordsforsøk (B: 39\%) enn hos de som døde (A: 24\%).

Også de som rapporterer selvskade (Gruppe E) hadde en øket forekomst av depresjon (E: $24 \%$ vs. D: 5\%), og atferdsforstyrrelse (E: $11 \%$ vs. D: $4 \%$ ), men klart lavere enn selvmordsgruppen (A) og gruppen med alvorlig selvmordsforsøk (B). Også når det gjelder lav selvfølelse skårer de med rapportert selvskade (E) mellom gjennomsnittsgruppen (D) og de med alvorlig selvmordsforsøk (B) (tabell 1).

I bivariat logistisk regresjon fant vi at effekten av depresjon var signifikant større for alvorlig selvmords- 
forsøk (B) enn for selvskade (E) (OR=3,1; CI=1,7-5,6; $\mathrm{p}>0,001)$, mens effekten av atferdsforstyrrelse ikke viste signifikant forskjell ( $\mathrm{OR}=2,2 ; \mathrm{CI}=0,9-5,5)$. De med alvorlig selvmordsfors $ø$ k (B) hadde signifikant lavere selvfølelse enn selvskaderne $(E)(p<0,001)(15)$.

\section{Forhold til andre}

De som rapporterer selvskade (E ) skårer også mellom gjennomsnittsgruppen $\mathrm{D}$ og de med alvorlig selvmordsfors $ø k(\mathrm{~B})$ når det gjelder opplevet ensomhet. De skulket skolen mer enn noen av de andre gruppene (D: $16 \%$, B: $24 \%$, E: $31 \%$; tabell 1). For begge disse faktorene er forskjellen fra gjennomsnittsungdom signifikant, mens det ikke er signifikante forskjeller mellom de med alvorlig selvmordsforsøk B og de med selvskade E i bivariat logistisk regresjon. De to suicidale gruppene rapporterer forholdsvis sjelden at de ikke har noen faste venner de pleier være sammen med (B: $17 \%$, E: $15 \%)$. Ut over det er forhold til jevnaldrende ulikt: de med alvorlig selvmordsforsøk (B) er oftest sammen med noen få faste venner eller alene (B: $43 \%$; E: $27 \%$; $\mathrm{OR}=2,3 ; \mathrm{CI}=1,2-4,2 ; \mathrm{p}<0,05)$, mens selvskaderne (E) i likhet med gjennomsnittsungdommen (D) oftest hører med i en gjeng (B: 39\%, E: 57\%, D: 57\%).

De med alvorlig selvmordsforsøk (B) søker sjelden støtte hos sine foreldre (gjennomsnittlig 0,8 ganger av 3 mulige ganger). Også selvskadere (E) søker noe sjeldnere foreldrestøtte enn gjennomsnittsungdommen
D (E: 1,6 ganger; D: 2,2 ganger; $p<0,001)$, men støtte fra venner søker de omtrent like ofte (E: 2,3 og D: 2,1 ganger av 3 mulige). Dette er langt oftere enn de med alvorlig selvmordsfors $ø \mathrm{k}$ (B: 1,4 ganger av 3 mulige).

\section{Multivariate analyser}

Psykisk helse og atferdsproblemer. Resultatene fra de multiple logistiske regresjonene der de suicidale gruppene A, B og E sammenliknes med sine respektive sammenlikningsgrupper (figur 1) etter at vi har kontrollert for andre variabler i likningen, er angitt i tabell 2. Hvilke variabler som er tatt inn i de enkelte analysene framgår av tabellen. Av de inkluderte variabler, er depresjon sterkt assosiert med suicidal atferd $(\mathrm{p}<0,001)$, enten det dreier seg om selvmord $(\mathrm{OR}=22,8)$, alvorlig selvmordsfors $ø \mathrm{k}(\mathrm{OR}=4,7)$ eller selvskade rapportert i en anonym spørreundersøkelse $(\mathrm{OR}=3,1)$ (Tabell 2). Det samme gjelder atferdsproblemer, selv om sammenhengen knapt er signifikant for de med rapportert selvskade $(\mathrm{OR}=2,6, \mathrm{p}=0,05)$. Bruk av rusmidler viser ingen signifikant sammenheng med suicidal atferd når vi kontrollerer for atferdsproblemer og de andre variablene. Det gjelder enten vi ser på de to gruppene uten dødelig utgang der vi har vurdert bruk av illegale rusmidler, eller vi ser på de som døde der hyppig bruk av rusmidler er registrert (Tabell 2).

Familieforhold. Vi ser en signifikant sammenheng mellom både selvmord og alvorlig selvmordsforsøk på

Tabell 1. Forekomst av risikofaktorer for suicidal atferd blant gjennomsnittsunge, blant unge med rapportert selvskade og unge med alvorlig selvmordsforsøk, alle i Akershus og Oslo 1993-94, samt blant unge døde av selvmord i Norge 1990-92.

\begin{tabular}{|c|c|c|c|c|}
\hline & $\begin{array}{c}\text { Gruppe D: } \mathrm{N}=1736 \\
\text { Vanlige unge i } \\
\text { Oslo/Akershus } \\
\mathrm{N}(\%)\end{array}$ & $\begin{array}{c}\text { Gruppe E: } \mathrm{N}=141 \\
\text { Rapportert } \\
\text { selvskade } \\
\mathrm{N}(\%)\end{array}$ & $\begin{array}{c}\text { Gruppe B: } \mathrm{N}=92 \\
\text { Alvorlig selv- } \\
\text { mordsforsøk } \\
\mathrm{N}(\%)\end{array}$ & $\begin{array}{c}\text { Gruppe A: } \mathrm{N}=129 \\
\text { Gjennomført } \\
\text { selvmord } \\
\mathrm{N}(\%)\end{array}$ \\
\hline Piker & $897(52)$ & $109(77)$ & $93(90)$ & $30(23)$ \\
\hline SES III, IV, eller trygd & $623(37)$ & $59(42)$ & $63(69)$ & \\
\hline Uten 2 biologiske foreldre & $592(34)$ & $59(44)$ & $58(63)$ & $66(52)$ \\
\hline Foreldre beruset & $123(7)$ & $18(13)$ & $33(36)$ & \\
\hline Depressive symptomer & $109(5)$ & $34(24)$ & $48(53)$ & $55(46)$ \\
\hline Atferdsproblemer & $72(4)$ & $15(11)$ & 17 (19) & $21(17)$ \\
\hline Omgåes en gjeng & $968(57)$ & $80(57)$ & $34(39)$ & \\
\hline Få venner & $557(33)$ & $28(27)$ & $37(43)$ & \\
\hline Ikke faste venner & $165(10)$ & $21(15)$ & $16(18)$ & \\
\hline Illegale rusmidler & $159(9)$ & $31(22)$ & $18(20)$ & \\
\hline Hyppig rusbruk & & & & $20(17)$ \\
\hline Skoleskulk & $275(16)$ & $43(31)$ & $22(24)$ & \\
\hline \multirow[t]{2}{*}{ Tidligere suicidal atferd } & $141(8)$ & Alle pr. def. & $35(39)$ & $27(24)$ \\
\hline & Skåre (SD) & Skåre (SD) & Skåre (SD) & \\
\hline Ber foreldre om støtte & $2,0(1,0)$ & $1,6(1,0)$ & $0,8(1,0)$ & \\
\hline Ber venner om støtte & $2,1 \quad(0,9)$ & $2,3(0,8)$ & $1,4(1,1)$ & \\
\hline Ber noen om støtte & $2,8(0,4)$ & $2,8(0,5)$ & $2,5(0,8)$ & \\
\hline Global selvfølelse & $3,0(0,6)$ & $2,6(0,6)$ & $2,1 \quad(0,7)$ & \\
\hline Ensomhet & $1,7(0,5)$ & $2,0(0,6)$ & $2,2(0,8)$ & \\
\hline
\end{tabular}

SES $=$ sosial klasse; $\mathrm{SD}=$ standardavvik 
den ene siden og familiestruktur (bo med to biologiske foreldre) på den andre siden. Ut over det har vi bare opplysninger om familieforhold for de som ikke døde (B og E). Både hyppig beruselse hos foreldre, lav sosial status, å bo uten to biologiske foreldre og lite oppsøkt støtte fra foreldre har signifikant sammenheng med alvorlig selvmordsforsøk (B) (tabell 2). Rapportert selvskade (E) er bare signifikant assosiert med lite støtte fra foreldre.

Forhold til venner. Vi mangler informasjon om de unge som tok sitt liv. Selvskadere E følte seg signifikant mer ensomme og de skulket skolen oftere enn gjennomsnittsungdom. De med alvorlig selvmordsforsøk $\mathrm{B}$ følte seg ikke ensomme når vi korrelerer for depresjon, men de ba sjelden venner om støtte.

Direkte sammenlikning mellom unge med selvmordsforsøk og unge med rapportert selvskade. Når disse to gruppene sammenliknes direkte i multivariat logistisk regresjon, finner vi signifikante forskjeller mellom dem for følgende variabler: Sosial klasse $(\mathrm{OR}=2,9 ; \mathrm{CI}=1,0-8,5 ; \mathrm{p}<0,05)$, foreldrestøtte $(\mathrm{OR}=3,1 ; \mathrm{CI}=1,6-6,0 ; \mathrm{p}<0,001)$, vennestøtte $(\mathrm{OR}=4,1$; $\mathrm{CI}=2,0-8,3 ; \mathrm{p}<0,001)$ og lav selvfølelse $(\mathrm{OR}=1,22$; $\mathrm{CI}=1,02-1,44 ; \mathrm{p}<0,05)$. I alle disse sammenlikningene var de med alvorlig selvmordsforsøk mest belastet (5).

\section{DISKUSJON}

I tråd med tallrike internasjonale publikasjoner finner vi at den viktigste risikofaktor for alle selvmordshandlinger er depresjon (17-20). Samtidig understreker de mange variabler med selvstendig innflytelse at selv- mordsatferd må forstås i en multifaktoriell sammenheng. Risikofaktorer for suicidal atferd i Norge er generelt i samsvar med funn fra andre vestlige land, selv om rusmiddelmisbruk og utagerende atferd i disse unge aldersgruppene er mindre prevalent $\mathrm{i}$ Norge enn $\mathrm{i}$ Finland og USA (17-19).

\section{Kvalitative og kvantitative forskjeller i risikofaktorer}

Psykiske og sosiale vansker. Unge med alvorlig selvmordsforsøk har høyere prevalens av samtlige risikofaktorer sammenliknet med de som rapporterer selvskade i befolkningen. Dermed står de fram som en mer belastet gruppe enn selvskadere, med et bredere register av problemer. Det må tas et visst forbehold fordi informasjon er samlet inn på ulik måte i de to gruppene. Imidlertid rapporteres ofte flere problemer ved selvutfylling i anonyme studier enn ved direkte intervju (21), og forskjellen kan være underrapportert. I vår undersøkelse har de som dør for egen hånd samme prevalens av psykiske lidelser som de som forsøker å ta sitt eget liv. Også dette må vurderes i lys av de ulike metodene anvendt for å innhente opplysninger. Unge selv rapporterer generelt mer problemer enn foreldre, slik at underrapportering høyst sannsynlig er langt større for de som er døde enn for de som ble møtt i et intervju (21). Undersøkelsene trekker derfor i retning $\mathrm{av}$ at det er et kontinuum $\mathrm{i}$ alvorlighetsgrad når det gjelder psykisk helse mellom de tre suicidale ungdomsgruppene. Forskjellene mellom gruppene er også tydelige, først og fremst er kjønnsforskjellene store, med langt flere gutter blant de som tar sitt eget liv. Når gutter og jenter innenfor selvmordsgruppen sammen-

Tabell 2. Uavhengig effekt av risikofaktorer for rapportert selvskade $(\mathrm{N}=141)$, alvorlig selvmordsforsøk $(\mathrm{N}=91)$ og selvmord $(\mathrm{N}=129)$, sammenliknet med gjennomsnittsungdom.

\begin{tabular}{lccc}
\hline & $\begin{array}{c}\text { Risiko for rapportert } \\
\text { selvskade } \\
\text { OR }(95 \% \mathrm{CI})\end{array}$ & $\begin{array}{c}\text { Risiko for alvorlig } \\
\text { selvmordsforsøk } \\
\text { OR }(95 \% \mathrm{CI})\end{array}$ & $\begin{array}{c}\text { Risiko for gjennomført } \\
\text { selvmord } \\
\text { OR }(95 \% \mathrm{CI})\end{array}$ \\
\hline SES III, IV, eller trygd & $1,2(0,8-1,8)$ & $2,4(1,1-5,5)^{*}$ & $2,4(1,1-5,4)^{*}$ \\
\hline Uten 2 biologiske foreldre & $1,2(0,8-1,8)$ & $2,4(1,1-5,4)^{*}$ & \\
\hline Foreldre beruset & $1,2(0,6-2,4)$ & $4,3(1,7-10,5)^{* *}$ & \\
\hline Depressive symptomer & $3,1(1,8-5,5)^{* * *}$ & $4,7(2,0-11,2)^{* * *}$ & $22,8(10,8-48,0)^{* * *}$ \\
\hline Atferdsproblemer & $2,6(1,0-6,8)$ & $9,4(2,1-41,4)^{* *}$ & $5,6(2,1-14,8)^{* * *}$ \\
\hline Omgåes en gjeng & 1,0 referanse & 1,0 referanse & \\
Få venner & $0,8(0,5-1,3)$ & $1,6(0,6-3,6)$ & \\
Ingen faste venner & $1,5(0,8-2,7)$ & $1,7(0,5-5,2)$ & \\
\hline Illegale rusmidler & $1,4(0,8-2,6)$ & $0,2(0,0-0,9)^{*}$ & \\
\hline Skulking & $1,7(1,01-1,15)^{*}$ & $1,4(0,5-3,6)$ & \\
\hline Ber foreldre om støtte & $1,2(1,0-1,5)^{*}$ & $3,3(2,1-5,3)^{* * *}$ & \\
\hline Ber venner om støtte & $0,8(0,6-1,1)$ & $3,3(2,0-5,5)^{* * *}$ & \\
\hline Ber ingen om støtte & $1,5(0,8-3,0)$ & $0,6(0,3-1,5)$ & \\
\hline Lav selvfølelse & $1,09(1,01-1,18)^{*}$ & $1,29(1,12-1,48)^{* * *}$ & \\
\hline Ensomhet & $1,13(1,01-1,26)^{*}$ & $0,88(0,75-1,05)$ & $1,1(0,5-2,4)$ \\
\hline Tidligere suicidal atferd & & & \\
\hline
\end{tabular}

Note: Odds ratio med 95\% konfidensintervall, stratifisert for alder og kjønn. Sammenlikningene er gjort mellom de med og de uten de analyserte karakteristika. $* * *=\mathrm{p}<0,001 * *=\mathrm{p}<0,01 * \mathrm{*}=0,05$

$\S$ Her refereres til hyppig bruk av rusmidler. 
liknes, finner en imidlertid små forskjeller i risikofaktorer (22).

Også unge som bor uten to biologiske foreldre har øket risiko for selvmord. Samtidig ser vi at flere blant de som forsøker selvmord (63\%) enn blant dem som begår selvmord (44\%) bor uten to biologiske foreldre. En nærliggende hypotese som bør undersøkes nærmere i senere studier kan formuleres slik: Sosiale problemer leder ofte til selvmordsatferd som sjelden progredierer til selvmord, mens psykisk lidelse i ungdomsårene, mindre påvirket av sosiale forhold, oftere fører til fullført selvmord. Et eksempel kunne være bipolar lidelse (23).

Når det gjelder andre problemer er det først og fremst de to gruppene med selvskade og med alvorlig selvmordsforsøk vi kan uttale oss om. En rekke faktorer har en selvstendig sammenheng med selvmordsforsøk som fører til sykehusinnleggelse. Disse faktorene er både knyttet til psykisk helse (depresjon, atferdsforstyrrelser, lav selvfølelse) og til sosiale forhold (lav sosial klasse, foreldre som ofte er beruset). Selv om prevalensen av psykiske lidelser er høyere for unge med selvmordsforsøk enn for selvskadere i befolkningen, skiller ikke psykiske lidelser mellom de to gruppene når de sammenliknes direkte i multivariat logistisk regresjon (15). Lav selvfølelse viser derimot signifikant forskjell, og er viktigere for de med alvorlig selvmordsforsøk. Lav selvfølelse kan være en medierende faktor som fører til at selvmordshandlingen blir mer alvorlig slik det også er beskrevet av andre (20). En alternativ forklaring kan ligge $i$ at undersøkelsen av de innlagte ungdommene ble foretatt umiddelbart etter selvmordshandlingen, $\mathrm{i}$ en periode da selvfølelsen var på det laveste. I befolkningsundersøkelsen varierte tiden mellom selvskaden og spørreskjemaundersøkelsen.

Forhold til andre. De klareste forskjellene finner vi når det gjelder forholdet til andre. Unge med alvorlig selvmordsforsøk hører sjelden med $\mathrm{i}$ en gjeng av unge, men har ofte en eller to venner de pleier å omgåes. De søker likevel sjelden støtte hos disse vennene når de har problemer, og får dermed lite beskyttelse. Det synes som det å søke slik vennestøtte har en viss beskyttende effekt mot alvorlig selvmordsforsøk. Dette er i tråd med Ystgaards funn (24) at sosial støtte fra venner og foreldre bufrer effekten av negative livshendelser, spesielt hos gutter.

De som innlegges etter selvmordsforsøk opplever seg som ensomme. Det kan skyldes en uttalt depresjon, idet ensomhet ikke har noen selvstendig innflytelse på alvorlig selvmordsforsøk. En annen mulig forklaring kan være at de ikke ønsker seg eller forventer nærhet på samme måte som de unge i befolkningsundersøkelsen.

De som rapporterer selvskade hører like ofte som gjennomsnittsungdom med i en gjeng. De skulker ofte skolen, bruker rusmidler og har økt forekomst av atferdsforstyrrelser. Dette tyder på at de ofte er integrert i grupper av unge som tøyer grenser. De søker ofte støtte fra venner, men det beskytter dem ikke mot selvskade, selv om det beskyttet mot mer alvorlige selvmordsforsøk.

Familieforhold. Studien understreker hvor viktig det er å ha et fortrolig forhold til sine foreldre, slik også Gould (25) har understreket. Å søke støtte hos sine foreldre $\mathrm{i}$ vanskelige situasjoner synes å ha en beskyttende effekt mot både selvskade og alvorlig selvmordsforsøk. De som skader seg, søker mindre foreldrestøtte enn gjennomsnittet, men allikevel langt oftere enn unge med alvorlig selvmordsforsøk. Det kan ha sammenheng med de klare forskjeller i familieforhold vi finner for de to suicidale gruppene. De med alvorlig selvmordsforsøk kommer fra lavere sosial klasse, ofte fordi foreldrene deres oftere lever av trygd (15). Foreldrene drikker mer, og virker mindre aktuelle som støttepersoner. De med alvorlig selvmordsforsøk har altså vanskeligere bakgrunn og kan av den grunn la være å søke støtte hjemme. En annen grunn til at de sjelden ber om støtte, kan være en følelse av å være en byrde for andre, noe en ofte støter på hos alvorlig deprimerte unge. Dette understreker at det ikke nødvendigvis dreier seg om foreldrenes evne eller vilje til å gi støtte, men om de unge faktisk søker slik støtte.

\section{Styrker og svakheter ved studiene}

I Norge er det ikke tidligere gjort grundige undersøkelser av barn og unge som har gjennomført selvmord eller vært innlagt for selvmordsforsøk. Det er ingen som tidligere har sammenliknet risikofaktorer for hospitaliserte selvmordsforsøk og for selvmordsforsøk som rapporteres i befolkningsundersøkelser. Siden en i selvmordsforebygging vanligvis appliserer kunnskap om en type selvmordsatferd til andre typer uten kvalifiserte forbehold, er en slik sammenlikning nyttig. Studienes styrke er de relativt komplette og omfattende utvalgene av ungdom. Spesielt for de unge med selvmordshandlinger uten dødelig utgang har vi undersøkt mange variabler og kan dermed undersøke hvordan ulike faktorer virker alene og i samspill.

Samtidig har studien en rekke svakheter. I casecontroll studien av selvmord er selvmordsgruppen studert retrospektivt, basert på opplysninger som i noen tilfeller sannsynlig er begrenset eller upålitelige, mens sammenlikningsgruppen er studert via selvrapportering. Dette vanskeliggjør også en sammenlikning med unge med andre typer selvmordsatferd. Tall knyttet til psykiske vansker, rusbruk og tidligere selvskade er minimumstall for de unge døde, og kan bare med betydelige forbehold sammenliknes med funn fra studien av non-fatale selvmordshandlinger. Bare når det gjelder demografiske data, knyttet til hvem de har vokst opp hos, har vi tilnærmet sammenliknbare data.

Også i sammenlikningen mellom de to gruppene med selvmordsforsøk og med selvskade er det problemer. Den ene gruppen er intervjuet direkte, mens den andre bare har fylt ut spørreskjema. Selv der intervjuobjektene har fylt ut de samme skjemaer, kan kontakten med intervjueren ha påvirket dem. Størst er problemene når det gjelder depressive symptomer, der 
personene har fylt ut ulike skjemaer (BDI og DMI), samtidig som en har en klinisk vurdering av den ene gruppen. Vi vet at korrelasjonen mellom selvrapportert depresjon og klinisk vurdert depresjon er moderat (Pearsons $\mathrm{r}=0,43$ ), og korrelasjonen mellom de to skjemaene varierer fra 0,66-0,83 (16). Disse metodiske problemene er mer detaljert beskrevet i tidligere publikasjoner $(5,16)$.

\section{KONKLUSJON}

Psykiske vansker er åpenbart assosiert med alle typer suicidal atferd, og sterkere jo alvorligere den suicidale handlingen er. Når det gjelder sosiale problemer og familieproblemer er bildet mindre entydig. Denne typen problemer er først og fremst assosiert med mer alvorlige selvmordsforsøk. En hypotese er at unge mennesker har håp om at de ytre omgivelsene kan endre seg, slik at problemer i omgivelsene ikke så ofte fører til håpløshet $\mathrm{og}$ selvmord $\mathrm{i}$ ung alder. Samfunnet formidler kanskje ikke samme grad av optimisme når unge mennesker står overfor alvorlig psykisk sykdom.

Vi ser også at unge som kan søke støtte fra andre nære personer sjelden foretar alvorlige selvmordsforsøk. Disse funnene støtter en hypotese framsatt av Lewinsohn (20) og Ystgaard (24); at mangel på støtte fungerer som mediatorer og bidrar til at selvmordshandlinger blir mer alvorlige. Også lav selvfølelse kan ha sammenheng med belastet familiebakgrunn og liten støtte, og gjennom en ond sirkel forsterke allerede eksisterende problemer.

Unge som har venner og færre familieproblemer kan også skade seg selv, slik vi fant hos $8,1 \%$ i befolkningsundersøkelsen. Å søke støtte i venneflokken beskytter ikke mot slik atferd, og kanskje er det noen ganger problemer i forhold til venner som kan føre til desperasjon og selvskade. Flere forhold tyder på at vennekretsen ofte er involvert i ungdommelig problematferd, som skulking, stoffbruk og liknende.

I nasjonal handlingsplan for selvmord er en rekke forebyggende tiltak nevnt (26). Også vår studie peker i retning av at tiltak for å forebygge selvmordsatferd må settes inn på mange plan. I Norge anvender svært mange unge skytevåpen som selvmordsmetode sammenliknet med andre vesteuropeiske land, og tiltak som reduserer unges tilgang til våpen og ammunisjon kan ha selvmordsforebyggende effekt. Innsatsen for å hjelpe unge med psykiske lidelser må økes. Innsatsen i forhold til diagnostisering og behandling av lidelsene bør bli bedre. Parallelt bør de unge styrkes ved at det arbeides med å bedre sosiale ferdigheter, bedre kommunikasjon i familiene og derigjennom selvfølelsen. Dette er særlig aktuelt for de som legges inn etter selvmordsforsøk. De mange som rapporterer selvskade er sjelden i kontakt med hjelpeapparatet (27), og vil trolig ha mer nytte av tiltak rettet mot større grupper. Endring i generelle holdninger til det å ha problemer kan være gunstig for unge som føler seg som en del av ungdomskulturen. Samtidig bør voksne som har kontakt med unge være oppmerksom på selvmordstanker blant unge, også blant de mer utagerende. Foreldrestøtte er nyttig, og mulig vil en samtale med en vanlig fornuftig voksen person også kunne redusere risikoen for mindre alvorlig selvskade.

\section{REFERANSER}

1. Gjertsen F. Utviklingstendenser i selvmord 1950-1995. Nytt $i$ Suicidologi 1998; 3: 8-11.

2. Rossow I, Wichstrom L. Parasuicide and use of intoxicants among Norwegian adolescents. Suicide Life Threat Behav 1994; 24: 174-183.

3. Wichstrom L. Predictors of adolescent suicide attempts. A national representative longitudinal study of Norwegian adolescents. J Am Acad Child Adolesc Psychiatry 2000; 39: 603-610.

4. Kjelsberg E, Neegard E, Dahl A. Suicide in adolescent psychiatric in-patients: incidence and protective factors. Acta Psychiatr Scand 1994; 89: 235-241.

5. Groholt B, Ekeberg O, Wichstrom L, Haldorsen T. Youth suicide in Norway, 1990-1992: a comparison between children and adolescents completing suicide and age- and gender-matched controls. Suicide Life Threat Behav 1997; 27: 250-263.

6. Beautrais AL, Joyce PR, Mulder RT. Psychiatric contacts among youths aged 13 through 24 years who have made serious suicide attempts. J Am Acad Child Adolesc Psychiatry 1998; 37: 504-511.

7. Wichstrom L. The emergence of gender difference in depressed mood during adolescence: the role of intensified gender socialization. Dev Psychol 1999; 35: 232-245.

8. Wichstrom L, Skogen K, Oia T. Increased rate of conduct problems in urban areas: what is the mechanism? $J$ Am Acad Child Adolesc Psychiatry 1996; 35: 471-479.

9. Kandel DB, Davies M. Epidemiology of depressed mood in adolescents: an empirical study. Arch Gen Psychiatry 1982; 39: 1205-1212.

10. Beck AT, Steer RA, Garbin MG. Pschycometric properties of the Beck Depression Inventory: twenty-five years of evaluation. Clin Psychol Rev 1988; 8: 77-100.

11. Russell D, Peplau LA, Cutrona CE. The revised UCLA Loneliness Scale: concurrent and discriminant validity evidence. J Pers Soc Psychol 1980; 39: 472-480. 
12. Harter S. Manual for the Self-Perception Profile for Adolescents. Boulder: University of Denver, 1988.

13. Wichstrom L. Harter's Self-Perception Profile for Adolescents: reliability, validity, and evaluation of the question format. J Pers Assess 1995; 65: 100-116.

14. Grøholt B. Suicide and suicide attempt among children and adolescents: A clinical and epidemiological study from Norway 1990-1994. Avhandling, Universitetet i Oslo, 1999.

15. Groholt B, Ekeberg O, Wichstrom L, Haldorsen T. Young suicide attempters: a comparison between a clinical and an epidemiological sample. $J$ Am Acad Child Adolesc Psychiatry 2000; 39: 868-875.

16. Breslow NE, Day NE. Statistical Methods in Cancer Research. Volume 1: The analysis of case-control studies. Lyon: IARC Scientific Publications, 1980.

17. Marttunen MJ, Aro HM, Henriksson MM, Lönnqvist JK. Mental disorders in adolescent suicide: DSM-III-R axes I and II diagnosis in suicide among 13-19-year-olds in Finland. Arch Gen Psychiatry 1991; 48: 834-839.

18. Shaffer D, Gould MS, Fisher P, Trautman P, Moreau D, Kleinman M, Flory M. Psychiatric diagnosis in child and adolescent suicide. Arch Gen Psychiatry 1996; 53: 339-348.

19. Brent DA. Risk factors for adolescent suicide and suicidal behavior: mental and substance abuse disorders, family environmental factors, and life stress. Suicide Life Threat Behav 1995; 25 Suppl: 52-63.

20. Lewinsohn PM, Rohde P, Seeley JR. Adolescent suicidal ideation and attempts: prevalence, risk factors, and clinical implications. Clin Psychol Sci Pract 1996; 3: 25-46.

21. Verhulst FC, van der Ende J. Agreement between parents' reports and adolescents' self-reports of problem behavior. J Child Psychol Psychiat 1992; 33: 1011-1023.

22. Groholt B, Ekeberg O, Wichstrom L, Haldorsen T. Sex differences in adolescent suicides in Norway, 19901992. Suicide Life Threat Behav 1999; 4: 295-308.

23. Geller B, Bolhofner K, Craney JL, Williams M, DelBello MP, Gundersen K. Psychosocial functioning in a prepubertal and early adolescent bipolar disorder phenotype. J Am Acad Child Adolesc Psychiatry 2000; 39: $1543-1548$.

24. Ystgaard M, Tambs K, Dalgard OS. Life stress, social support and psychological distress in late adolescence: a longitudinal study. Soc Psychiatry Psychiatr Epidemiol 1999; 34: 12-19.

25. Gould MS, Fisher P, Parides M, Flory M, Shaffer D. Psychosocial risk factors of child and adolescent completed suicide. Arch Gen Psychiatry 1996; 53: 1155-1162.

26. Helsedirektoratet. Nasjonalt program for forebygging av selvmord i Norge. Helsedirektoratets veiledningsserie, 1993.

27. Rossow I, Wichstrom L. Når nøden er størst - er hjelpen nærmest? Tidsskr Nor Laegeforen 1997; 117: 17401743. 